\title{
PENGEMBANGAN GAME EDUKASI SATUA BALI “PAN CUBLING” BERBASIS ANDROID
}

\author{
I Wayan Putu Adi Wiguna ${ }^{1}$, I Ketut Resika Arthana ${ }^{2}$, I Made Putrama ${ }^{3}$ \\ Jurusan Pendidikan Teknik Informatika/ Universitas Pendidikan Ganesha \\ Singaraja, Indonesia
}

e-mail: wynwiguna@gmail.com ${ }^{1}$, resika@undiksha.ac.id ${ }^{2}$, made.putrama@undiksha.ac.id ${ }^{3}$

\begin{abstract}
Abstrak
Penelitian ini bertujuan untuk melestarikan kebudayaan di Bali dengan membantu masyarakat khususnya kalangan remaja untuk dapat mengetahui satua Bali Pan Cubling dengan bantuan media teknologi dengan cara mengajak remaja bermain Game Edukasi Satua Bali "Pan Cubling" berbasis android dengan objek 2D. Game Edukasi Satua Bali "Pan Cubling" Berbasis Android memiliki 4 stage game dan setiap stage terdapat 4 level permainan. Stage 1 pemain berusaha mempertahankan pisang dari serbuan kera, Stage 2 pemain mengusir kera agar tidak masuk ke dalam rumah, Stage 3 menggali tanah sebagai kuburan Pan Cubling, dan Stage 4 merangkai puzzle yang digunakan untuk menutupi lubang kuburan. Metode yang digunakan adalah proses System Development Life Cycle dalam bentuk sekuensial linier atau model air terjun (waterfall). Hasil akhir dari project penelitian ini berupa aplikasi game yang berisikan aksi dan cerita yang dapat diinstal pada smartphone android. Game ini sebagai media bermain sekaligus media belajar mengenal satua Bali Pan Cubling.
\end{abstract}

Kata kunci: Satua Bali, Pan Cubling, Stage, Game, 2 dimensi, Android

\begin{abstract}
This research as an effort in preserving one of the culture in Bali is to help the community, especially among teenagers to be able to know Balinese Story Pan Cubling with the help of technology media by inviting teenagers to play Saturn Bali Satisfaction Game "Pan Cubling" based on android with object 2D Education Games Satua Bali "Pan Cubling" Android based has 4 stage games and each stage there are 4 levels of the game. Stage 1 players try to defend bananas from an ape attack, Stage 2 players drove monkeys out of the house, Stage 3 dugs the ground as Pan Cubling's grave, and Stage 4 assembles the puzzle used to cover the cemetery hole. The method used is research and development using System Development Life Cycle process in the form of sequential linear or waterfall model. The end result of this research project is a game application that contains action and story that can be installed on android smartphone. This game application can be used as a media to play as well as learn to know the Balinese story of Pan Cubling.
\end{abstract}

Keywords : Balinese Story, Pan Cubling, Stage, Game, 2 Dimension, Android 


\section{PENDAHULUAN}

Pulau Bali selain dikenal sebagai pulau dewata atau pulau seribu pura juga dikenal dengan pulau yang memiliki beragam kebudayaan dan tradisi. Salah satu budaya yang dimiliki oleh Bali adalah budaya dibidang sastra. Kata sastra dalam Bahasa Sansekerta yaitu "shastra" yang merupakan kata serapan dari bahasa Sansekerta "Sastra", yang berarti "teks yang mengandung instruksi - instruksi atau pedoman - pedoman, dari kata dasar 'Sas' yang berarti "instruksi" atau "ajaran" dan 'Tra' yang berarti "alat" atau "sarana"[1]. Di Bali sendiri kesusastraan sangatlah melekat erat dalam kehidupan masyarakat Bali. Baik yang digunakan dalam kegiatan keagamaan atau sebagai media hiburan. Salah satu contoh kesusastraan Bali yang dipakai sebagai media hiburan contohnya adalah cerita yang biasa disebut "Satua". Secara sempit yang disebut Satua Bali adalah satua - satua yang penyebarannya dari mulut - mulut dan tidak diketahui siapa penciptanya [2]. Satua Bali berasal dari karya - karya pengarang, baik yang berbahasa bali maupun yang berbahasa Jawa kuna. Satua - satua Bali baik yang masih lisan maupun yang sudah dicetak, banyak ditemukan di masyarakat. Satua Bali memiliki hubungan dengan kehidupan sehari - hari misalnya tentang kejujuran, kesetiaan, dan tidak boleh memaksakan kehendak. Orang tua zaman dulu sering menceritakan satua Bali kepada anak anaknya sebagai dongeng pengantar tidur.

Salah satu satua Bali yang sering diceritakan oleh orang tua kepada anaknya menjelang tidur adalah Satua Pan Cubling. Dimana dalam satua tersebut diceritakan seorang lelaki duda yang tinggal bersama putri semata wayangnya di pinggir hutan di sebuah desa. Dimana pekerjaan sehari hari lelaki tersebut sebagai petani. Hasil pertanian yang dihasilkan adalah pisang dan berbagai macam ubi. Namun ladang petani tersebut sering dirusak oleh gerombolan kera yang hidup ditengah hutan tersebut. Segala jenis tanaman yang siap dipanen selalui didahului oleh kera tersebut. Tak hanya merusak tanaman yang ada di ladang tersebut, gerombolan kera tersebut juga datang ke rumah Pan Cubling untuk mengambil makanan yang ada dirumah Pan Cubling dengan paksa. Tak hanya sampai di situ, seekor kera yang merupakan raja gerombolan yakni I Murkati bahkan berani untuk meminang anak Pan Cubling yakni Ni Cubling untuk dijadikan sebagai istri Murkati. Pan Cubling akhirnya mencari cara untuk menghentikan keganasan gerombolan tersebut yaitu dengan berpura - pura mati. Sebelum Pan Cubling berpura - pura mati, dia berpesan kepada anaknya ketika kera tersebut datang disuruh untuk membuat liang kuburan untuk makam Pan Cubling. Kemudian setelah para kera tersebut selesai membuat liang kuburan tersebut, maka para kera disuruh untuk masuk ke dalam liang kuburan tersebut. Ketika para kera tersebut sudah masuk ke dalam liang kuburan tersebut, maka ditutuplah liang kuburan tersebut dengan penutup dari anyaman bambu (galar) dan kera tersebut disiram dengan air panas sehingga kera tersebut mati. Pesan moral yang bisa dipetik dari cerita tersebut adalah janganlah pernah mengambil sesuatu yang bukan milik kita dengan paksa[3]. Di era globalisasi ini perkembangan teknologi sangat pesat sehingga semakin menurunkan minat anak - anak terhadap Satua Bali. Hal ini disebabkan makin merebaknya arus informasi dari penjuru dunia melalui media elektronik seperti televisi. Hampir setiap hari televisi menyuguhkan dongeng berupa film kartun. Kebanyakan film kartun tersebut adalah film kartun impor yang sangat digemari anak anak. Dibandingkan dongeng televisi, mendongeng secara langsung jauh lebih efektif dalam mendidik anak-anak sejak dini. Cerita dongeng memiliki nilai-nilai kebaikan seperti kejujuran, kesetiaan kerja keras, hingga sopan santun. Nilai-nilai ini akan dapat diserap anak-anak kalau dongeng tersebut dapat disampaikan dengan baik dan benar.

Masyarakat Bali pada umumnya kurang mengetahui satua Bali. Dari 20 responden, $79 \%$ menyatakan tidak mengetahui satua Bali sedangkan 
sebanyak $21 \%$ menyatakan mengetahui satua Bali. Hal ini tentu sangat memprihatinkan karena satua Bali merupakan salah satu unsur kebudayaan dibidang kesusastraan yang dimiliki oleh Bali. Sudah seharusnya masyarakat Bali mengenal kebudayaan mereka sendiri yang merupakan warisan leluhur.

Solusi yang perlu dibuat dari permasalahan tersebut adalah dengan memanfaatkan perkembangan teknologi. Dengan bantuan teknologi upaya dalam melestarikan kebudayaan Bali terutama Satua Bali dapat diupayakan. Dengan bantuan teknologi kita dapat memperkenalkan satua Bali kepada generasi muda. Game selain untuk sebagai hiburan dan tempat untuk menghilangkan stress, game juga bisa dijadikan alternatif media belajar bagi anak-anak. Contohnya adalah dengan menterjemahkan satua Bali ke dalam game edukasi.[4]

Game edukasi unggul dalam beberapa aspek jika dibandingkan dengan metode pembelajaran konvensional, diantaranya adanya animasi yang dapat meningkatkan daya ingat sehingga anak dapat menyimpan materi pelajaran dalam waktu yang lebih lama dibandingkan dengan metode pengajaran konvensional.

\section{KAJIAN TEORI}

\section{Satua Bali}

Satua Bali adalah salah satu bentuk Kesusastraan Bali purwa yaitu gancaran, yang sering disebut sastra lisan. Secara sempit yang disebut Satua Bali adalah Satua-Satua yang penyebarannya dari mulut ke mulut dan tidak diketahui siapa penciptanya. Dari cerita tersebut kita dapat mengetahui di mana, bagaimana, dan apa yang dialami oleh pelaku cerita dari awal sampai akhir, pelaku cerita dapat manusia, binatang, maupun, manusia.

Satua Bali di bagi menjadi tiga jenis, yaitu Satua Bali yang berbentuk legenda, Satua Bali yang berbentuk mite, dan Satua Bali yang berbentuk dongeng. Kebanyakan Satua Bali yang sering kita dengar adalah Satua Bali yang berbentuk dongeng, yang banyak mengambil nama-nama binatang sebagai pemeran ceritanya.

Satua Bali Pan Cubling
Diceritakan seorang lelaki duda yang tinggal bersama putri semata wayangnya di pinggir hutan di sebuah desa. Dimana pekerjaan sehari - hari lelaki tersebut sebagai petani. Hasil pertanian yang dihasilkan adalah pisang dan berbagai macam ubi. Namun ladang petani tersebut sering dirusak oleh gerombolan kera yang hidup ditengah hutan tersebut. Segala jenis tanaman yang siap dipanen selalui didahului oleh kera tersebut. Tak hanya merusak tanaman yang ada di ladang tersebut, gerombolan kera tersebut juga datang ke rumah Pan Cubling untuk mengambil makanan yang ada dirumah Pan Cubling dengan paksa. Tak hanya sampai di situ, seekor kera yang merupakan raja gerombolan yakni I Murkati bahkan berani untuk meminang anak Pan Cubling yakni Ni Cubling untuk dijadikan sebagai istri I Murkati. Pan Cubling akhirnya mencari cara untuk menghentikan keganasan gerombolan tersebut yaitu dengan berpura - pura mati. Sebelum Pan Cubling berpura - pura mati, dia berpesan kepada anaknya ketika kera tersebut datang disuruh untuk membuat liang kuburan untuk makam Pan Cubling. Kemudian setelah para kera tersebut selesai membuat liang kuburan tersebut, maka para kera disuruh untuk masuk ke dalam liang kuburan tersebut. Ketika para kera tersebut sudah masuk ke dalam liang kuburan tersebut, maka ditutuplah liang kuburan tersebut dengan penutup dari anyaman bambu (galar) dan kera tersebut disiram dengan air panas sehingga kera tersebut mati. Pesan moral yang bisa dipetik dari cerita tersebut adalah janganlah pernah mengambil sesuatu yang bukan milik kita dengan paksa.

Android

Android adalah sistem operasi berbasis linux yang dipergunakan sebagai pengelola sumber daya perangkat keras, baik untuk ponsel, smartphone, dan juga PC Tablet. Secara umum Android adalah platform yang terbuka (Open Source) bagi para pembembang untuk menciptakan aplikasi mereka sendiri untuk digunakan oleh berbagai piranti bergerak[5]. Android 
memiliki banyak kelebihan, tidak hanya dari segi harga yang terbilang terjangkau, namun juga mampu digunakan di berbagai segmen, mulai dari kalangan menengah, bawah, maupun eksekutif muda. Android dikatakan jawaban dari keberagaman masyarakat perkotaan, mengingat mereka mempunyai berbagai kebutuhan dan pekerjaan yang harus dilakukan dalam waktu yang bersamaan. Berkat fitur yang selalu update, keberadaan Android mencuri perhatian penggunanya. Oleh sebab itu, pertumbuhannya dari tahun ke tahun dapat terlihat secara signifikan. Berikut akan dijelaskan versi-versi Android yang ada saat ini dan presentase jumlah pengguna di tiap - tiap versi yaitu Android versi 1.1, Android versi 1.5 (Cupcake), Android versi 1.6 (Donut), Android versi 2.0/2.1 (Éclair), Android versi 2.2 (Froyo), Android versi 2.3 (Gingerbread), Android versi 3.0 (Honeycomb), Android versi 4.0 (Ice Cream Sandwich), Android versi 4.1 (Jelly Bean), Android versi 4.4 (KitKat), dan yang terakhir Android versi 5.0 (Lolipop).

\section{Smartphone}

Smartphone berasal dari bahasa inggris yang artinya ponsel pintar atau ponsel cerdas. Maksudnya adalah telepon seluler atau telepon genggam yang memiliki kemampuan tinggi dengan fungsi menyerupai komputer [6]. Singkatnya, smartphone adalah perangkat yang memungkinkan anda melakukan panggilan telepon, sekaligus memiliki fitur yang di masa lalu hanya bisa ditemukan pada personal digital assistant (PDA) atau komputer - seperti kemampuan untuk mengirim dan menerima e-mail dan editing dokumen. Berikut aplikasi atau fitur yang pada umumnya terdapat pada smartphone:

\begin{tabular}{|l|l|l|}
\hline Kelompok & $\begin{array}{l}\text { Fitur yang } \\
\text { digunakan }\end{array}$ & $\begin{array}{l}\text { Keterang } \\
\text { an }\end{array}$ \\
\hline Browser & - Google & \multicolumn{1}{|c|}{ Brows } \\
& Chrome & er \\
& - Firefox & merupaka \\
& - Operami \\
ni & n program \\
& - Safari & $\begin{array}{l}\text { aplikasi } \\
\text { yang di } \\
\text { rancang }\end{array}$ \\
\hline
\end{tabular}

\begin{tabular}{|l|l|l|}
\hline Kelompok & $\begin{array}{l}\text { Fitur yang } \\
\text { digunakan }\end{array}$ & Keterang \\
an
\end{tabular}




\begin{tabular}{|l|l|l|}
\hline Kelompok & $\begin{array}{l}\text { Fitur yang } \\
\text { digunakan }\end{array}$ & Keterang \\
an
\end{tabular}

\begin{tabular}{|c|c|c|}
\hline Kelompok & $\begin{array}{l}\text { Fitur yang } \\
\text { digunakan }\end{array}$ & $\begin{array}{l}\text { Keterang } \\
\text { an }\end{array}$ \\
\hline & & $\begin{array}{l}\text { dokumen, } \\
\text { tapi juga } \\
\text { bisa } \\
\text { melakuka } \\
\mathrm{n} \text { editing } \\
\text { (penyunti } \\
\text { ngan). }\end{array}$ \\
\hline $\begin{array}{l}\text { Penjadwal } \\
\text { an }\end{array}$ & $\begin{array}{l}\text { - Kalender } \\
\text { - Jam } \\
\text { - Alarm } \\
\text { - Note } \\
\text { - Evernote } \\
\text { - Memo }\end{array}$ & $\begin{array}{l}\text { Aplika } \\
\text { si ini } \\
\text { dapat } \\
\text { membuat } \\
\text { sebuah } \\
\text { daftar } \\
\text { panjang } \\
\text { kegiatan } \\
\text { yang ingi } \\
\text { n atau } \\
\text { harus } \\
\text { dila- } \\
\text { kukan, } \\
\text { dan fitur } \\
\text { ini akan } \\
\text { menginga } \\
\text { tkan } \\
\text { pengguna } \\
\text {-nya. } \\
\text { Catatan } \\
\text { yang disi- } \\
\text { mpan pun } \\
\text { memungki } \\
\text { nkan } \\
\text { pengguna } \\
\text { nya untuk } \\
\text { mem- } \\
\text { bagikan } \\
\text { daftar } \\
\text { kegiatan } \\
\text { dengan } \\
\text { orang } \\
\text { lain. }\end{array}$ \\
\hline $\begin{array}{l}\text { Perhitung } \\
\text { an }\end{array}$ & $\begin{array}{l}\text { - Kalkulato } \\
r\end{array}$ & $\begin{array}{l}\quad \text { Maha } \\
\text { siswa dan } \\
\text { dosen } \\
\text { eksakta } \\
\text { akan } \\
\text { banyak } \\
\text { menggun } \\
\text { akan kal- } \\
\text { kulator } \\
\text { sebagai }\end{array}$ \\
\hline
\end{tabular}




\begin{tabular}{|c|c|c|}
\hline Kelompok & $\begin{array}{l}\text { Fitur yang } \\
\text { digunakan }\end{array}$ & $\begin{array}{l}\text { Keterang } \\
\text { an }\end{array}$ \\
\hline & & $\begin{array}{l}\text { teman } \\
\text { mengerja } \\
\text { kan tugas } \\
\text { ataupun } \\
\text { menghitu } \\
\text { ng angka- } \\
\text { angka } \\
\text { statistika. } \\
\text { Untuk } \\
\text { mem- } \\
\text { permudah } \\
\text { dosen } \\
\text { dan } \\
\text { mahasisw } \\
\text { a dalam } \\
\text { mengh- } \\
\text { itung } \\
\text { angka, } \\
\text { smart- } \\
\text { phone } \\
\text { menyedia } \\
\text { kan fitur } \\
\text { kalkulator. }\end{array}$ \\
\hline $\begin{array}{l}\text { Penyimpa } \\
\text { nan Data }\end{array}$ & $\begin{array}{l}\text { - Dropbox } \\
\text { - OneDrive } \\
\text { - Google } \\
\text { Drive } \\
\text { - Kontak } \\
\text { - Galeri }\end{array}$ & $\begin{array}{l}\text { Untuk } \\
\text { menganti- } \\
\text { sipasi } \\
\text { kejadian } \\
\text { data yang } \\
\text { diperluka } \\
\mathrm{n} \text { tapi } \\
\text { lupa } \\
\text { dibawa } \\
\text { dapat } \\
\text { disiasati } \\
\text { dengan } \\
\text { menyimpa } \\
\mathrm{n} \text { data- } \\
\text { data } \\
\text { penting } \\
\text { terlebih } \\
\text { dahulu } \\
\text { atau lebih } \\
\text { tepatnya } \\
\text { menguplo } \\
\text { ad data } \\
\text { ke akun } \\
\text { Dropbox. } \\
\text { Terdapat } \\
\text { pula fitur }\end{array}$ \\
\hline
\end{tabular}

\begin{tabular}{|c|c|c|}
\hline Kelompok & $\begin{array}{l}\text { Fitur yang } \\
\text { digunakan }\end{array}$ & $\begin{array}{l}\text { Keterang } \\
\text { an }\end{array}$ \\
\hline & & $\begin{array}{l}\text { Kontak } \\
\text { dan galeri } \\
\text { yang } \\
\text { berfungsi } \\
\text { untuk } \\
\text { menyimpa } \\
\text { n data } \\
\text { berupa } \\
\text { gabar dan } \\
\text { nomer } \\
\text { Telefon. }\end{array}$ \\
\hline $\begin{array}{l}\text { Dokument } \\
\text { asi }\end{array}$ & $\begin{array}{l}\text { - Kamera } \\
\text { - Video } \\
\text { - Recorder }\end{array}$ & \begin{tabular}{l}
\multicolumn{1}{c}{ Untuk } \\
melakuka \\
$\mathrm{n}$ \\
dokument \\
asi, baik \\
berupa \\
gambar \\
maupun \\
suara.
\end{tabular} \\
\hline Translator & - Kamus & \begin{tabular}{l}
\multicolumn{1}{c}{ Fitur } \\
smartpho \\
ne \\
menyedia \\
kan \\
berbagai \\
jenis \\
kamus \\
mulai dari \\
kamus \\
bahasa \\
Indonesia \\
- Inggris, \\
atau \\
kamus \\
besar \\
bahasa \\
Indonesia \\
' atau \\
kamus \\
bahasa \\
lainnya \\
yang bisa \\
di \\
download \\
secara \\
gratis.
\end{tabular} \\
\hline
\end{tabular}

Game 
Kata Game berasal dari bahasa Inggris yang berarti permainan. Permainan dalam hal ini merujuk kepada pengertian "kelincahan intelektual". Game juga diartikan sebagai arena keputusan dari aksi pemainnya karena ada target - target yang ingin dicapai, kelincahan intelektual pada tingkat tertentu juga merupakan ukuran sejauh mana game itu menarik untuk dimainkan secara maksimal. Pada era globalisasi saat ini, para pengelola industri game berlomba - lomba untuk menciptakan game yang lebih nyata dan lebih menarik untuk para pemainnya. Secara garis besar Game terbagi menjadi beberapa tipe atau genre yaitu board game, Arcade, Action, Shooting, Fighting, Racing, Simulation, dan Role Playing Game[7].

\section{METODE}

Pengembangan aplikasi Game Edukasi Satua Bali "Pan Cubling" Berbasis Android ini menggunakan siklus hidup pengembangan perangkat lunak SDLC (Software Development Life Cycle) dalam bentuk sekuensial linier atau model waterfall. Sekuensial linier mengusulkan pendekatan kepada perkembangan perangkat lunak yang sistematik dan sekuensial yang mulai pada tingkat dan kemajuan sistem pada seluruh analisis, design, kode, pengujian, dan pemeliharaan.

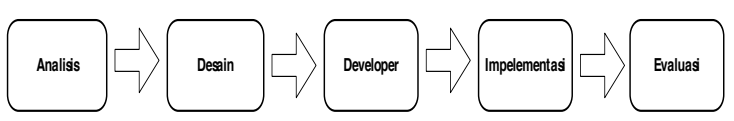

Gambar 1 Model Sekuensial Linier

Analisis Kebutuhan Perangkat Lunak

Tahap ini merupakan pengumpulan informasi dan kebutuhan secara lengkap kemudian dianalisis dan didefinisikan kebutuhan yang harus dipenuhi oleh aplikasi yang akan dibangun. Pada tahap ini dilakukan pencarian referemsi mengenai teori - teori yang diperlukan dan bagaimana menerapkannya dalam teknologi berbasis Android. Terdapat 2 proses yaitu :

1) Kebutuhan Fungsional

2) Kebutuhan Non-Fungsional

Perancangan/Desain

1) Perancangan Umum

Gambar 2 Use Case Diagram
Use Case Diagram menggambarkan fungsionalitas dari Game Edukasi Satua Bali "Pan Cubling". Dalam Use case diagram terdapat satu buah actor yaitu pengguna aplikasi. Pengguna aplikasi dalam hal ini dapat berinteraksi dengan sistem diantaranya pengguna aplikasi dapat melihat menu utama, dapat memilih memulai Game, melihat tutorial Game, memainkan Game stage, membaca cerita, melihat tentang aplikasi, dan keluar aplikasi.

2) Activity Diagram Memulai Game Edukasi Satua Bali "Pan Cubling"

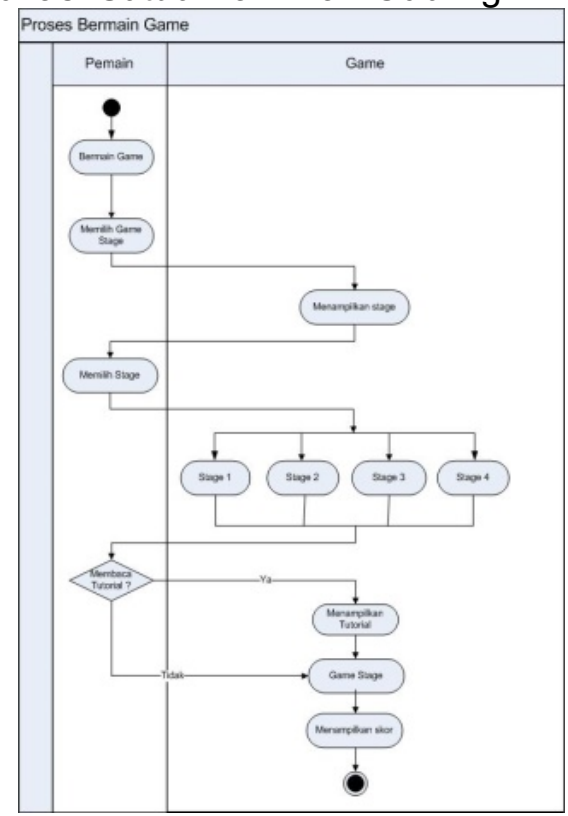

Gambar 3 Activity Diagram Memulai Game Edukasi Satua Bali "Pan Cubling"

Dalam activity diagram menggambarkan alur sistem tahapan dalam bermain game. Diawal pengguna aplikasi memilih mulai game. Setelah itu sistem akan menampilkan menu memilih game stage. Setelah ditampilkan stage game, pemain dapat memilih. Setelah memilih stage game, maka akan muncul menu tutorial. Di dalam menu menu tutorial terdapat cara memainkan game pada masing - masing stage

tentang aplikasi. Pemain memilih menu tentang untuk melihat informasi tentang aplikasi Game "Pan Cubling".

Perancangan Perangkat Lunak

1) Perancangan Skenario Game Merancang jalan cerita/alur bermain game. 
2) Perancangan Antar Muka

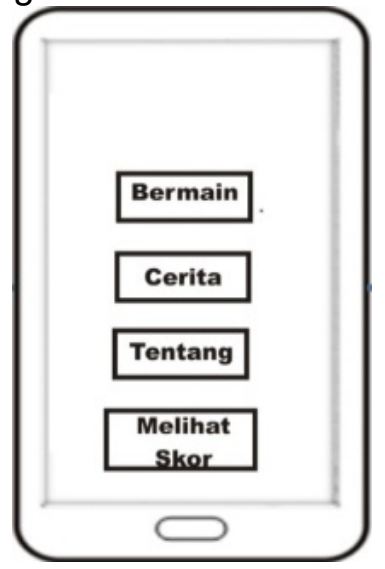

Gambar 4 Rancangan Antarmuka Menu Utama

3) Desain Karakter

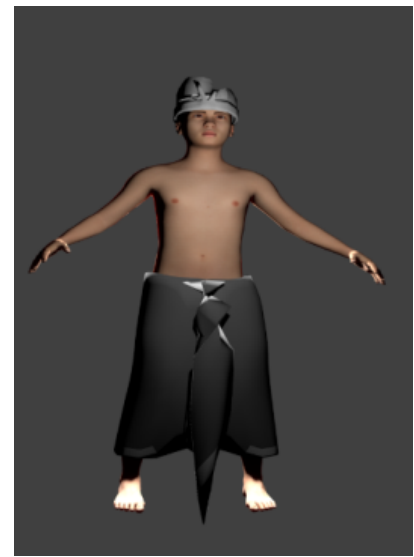

Gambar 5 Desain Pan Cubling

Pan Cubling merupakan tokoh utama dalam game ini. Ditampilkan sebagai sosok petani yang dengan gigih mempertahankan tanaman yang ada di ladangnya dan makanan yang ada di dalam rumahnya dari gangguan monyet.

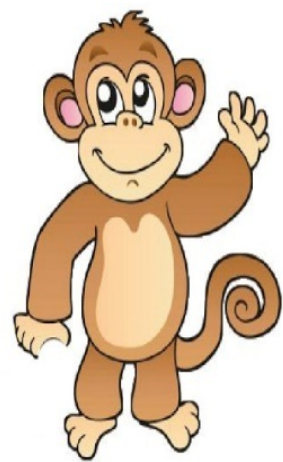

Gambar 6 Karakter Monyet

Monyet adalah karakter antagonis dalam game ini. Diceritakan sebagai musuh utama Nang Cubling yang selalu mencuri buah yang ada di ladang dan masuk ke rumah Nang Cubling untuk mengambil makanan apabila di ladang sudah tidak ada buah.

\section{HASIL DAN PEMBAHASAN}

Hasil

1. Lingkup Pengembangan Perangkat Lunak

a) Perangkat lunak yang digunakan dalam proses pengembangan aplikasi ini antara lain Sistem Operasi Microsoft Windows 7 Ultimate, Android Studio ver. 2.2.3, AndEngine Library, Adobe Photoshop CS6, dan Audacity.

b) Perangkat Keras

(1) Laptop Acer Aspire

(2) Intel ${ }^{\circledR}$ Core i3 M350 2,27Ghz RAM $1.00 \mathrm{~GB}$

(3) Harddisk $320 \mathrm{~GB}$

(4) VGA Intel HD Graphics

(5) Dilengkapi alat input dan output

c) Implemetansi Aplikasi merupakan spesifikasi perangkat yang digunakan untuk implementasi Game Edukasi Satua Bali "Pan Cubling" Berbasis Android perangkat yang digunakan dalam mengimplementasikan game Pan Cubling antara lain; 1)Smartphone Asus Fonepad 7, 2)Processor Intel Inside 1.2Ghz, 3)Monitor 5 inch, 4)Resolusi $720 \times 1280$ pixels, 5)RAM 1 GB, 6)Android 4.4 Kitkat.

2. Batasan Implementasi Perangkat Lunak

a) Pada lingkungan perangkat lunak, aplikasi Game Edukasi Satua Bali "Pan Cubling" berbasis Android dijalankan pada Sistem Android 4.1 JellyBean keatas.

b) Pada lingkungan perangkat keras, aplikasi Game Edukasi Satua Bali "Pan Cubling" dijalankan pada lingkungan sebagai berikut. Percobaan terhadap 5 smartphone ditemukan hasil, bahwa aplikasi masih dapat berjalan pada smartphone android RAM 512 MB dengan resolusi layar $320 \times 480$ GPU kelas low-end, namun ketika dijalankan prosesnya mengalami penurunan kinerja seperti membuka stage lambat, lagging ketika dimainkan dibeberapa stage. 
3. Implementasi Perangkat Lunak

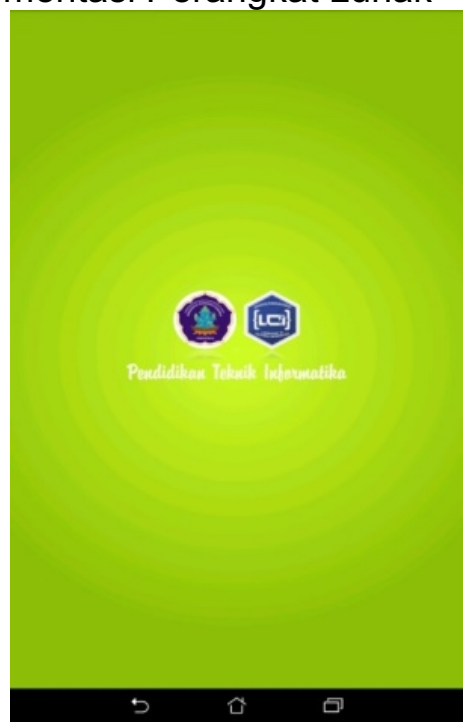

Gambar 7 Implementasi Splash Screen Tampilan awal (splash screen) akan ditampilkan ketika pertama kali membuka aplikasi. Tampilan gambar yang ditampilkan berupa logo Undiksha, logo LCl (Laboratory Cultural Of Informatics), dan berisikan nama jurusan Pendidikan Teknik Informatika di bawah logo Undiksha dan $\mathrm{LCl}$.

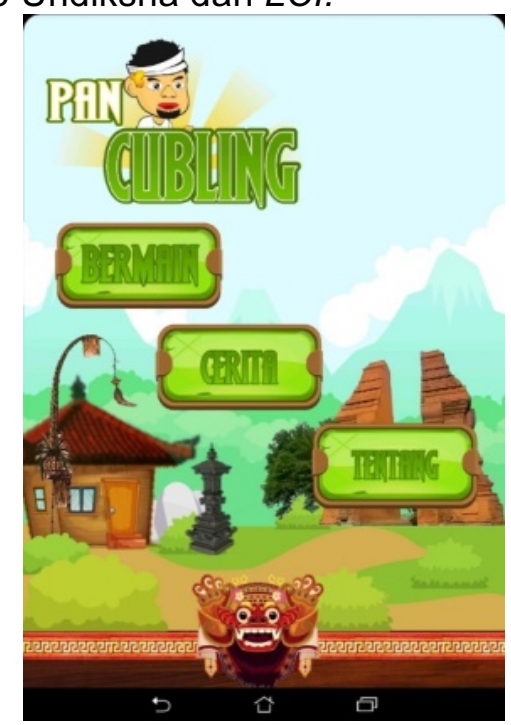

Gambar 4 Implementasi Tampilan Menu Utama

Tampilan menu utama akan menampilkan 3 menu utama, yaitu menu "Bermain", "Cerita", dan "Tentang". Pada menu "Bermain" terdapat stage game dan level game. Menu Cerita terdapat cerita "Pan Cubling" yang disertai dengan narasi atau dubbing. Dan untuk menu "Tentang" terdapat informasi tentang pengembang game edukasi satua Bali "Pan Cubling".

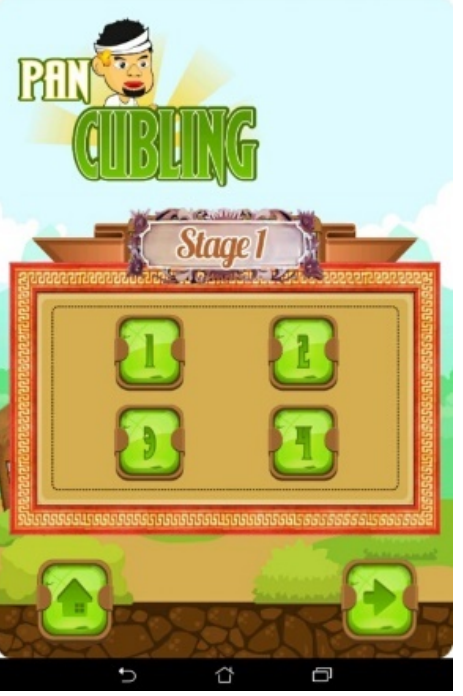

Gambar 9 Implementasi Tampilan Game Stage 1

Di dalam game stage 1, terdapat pilihan 4 level yang harus dimainkan dan juga terdapat dua tombol yakni tombol home 들 yang berfungsi sebagai tombol untuk kembali ke menu utama dan tombol next $\Rightarrow$ yang berfungsi sebagai tombol untuk masuk ke stage berikutnya.
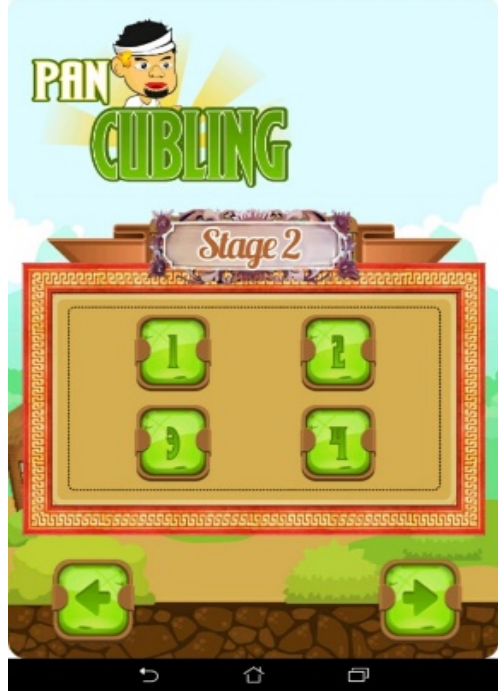

Gambar 10 Implementasi Tampilan Game Stage 2

Di dalam game stage 2, terdapat pilihan 4 level yang harus dimainkan. Pemain memerankan karakter Pan Cubling dan diminta untuk menyelesaikan permainan sesuai yang tertera dalam tutorial dengan menggerakkan karakter "Pan 
Cubling" ke arah gerombolan kera yang akan masuk ke dalam rumah.

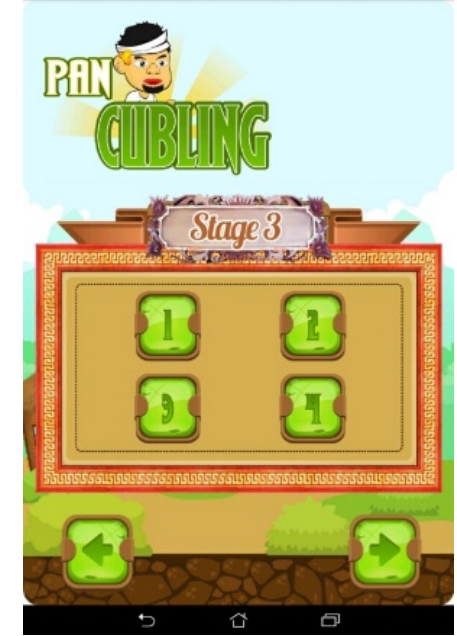

Gambar 11 Implementasi Tampilan Game Stage 3

Di dalam game stage 3, terdapat pilihan 4 level yang harus dimainkan. Pemain mempunyai tugas untuk membantu para kera yang akan menggali tanah untuk lubang kuburan dengan cara menekan tombol yang berisi gambar cangkul di layar dengan ketentuan bar pencapaian dan timer.

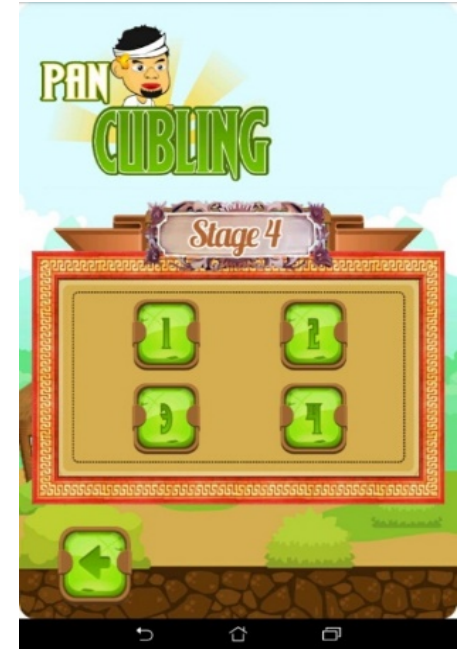

Gambar 14 Implementasi Tampilan Game Stage 4

Di dalam game stage 4 terdapat pilihan 4 level yang harus dimainkan. Pemain mempunyai tugas untuk merangkai puzzle yang tersedia sesuai dengan toast yang tertera ketika awal permainan. Jumlah puzzle yang akan dirangkai ditentukan sesuai dengan level yang dimainkan.

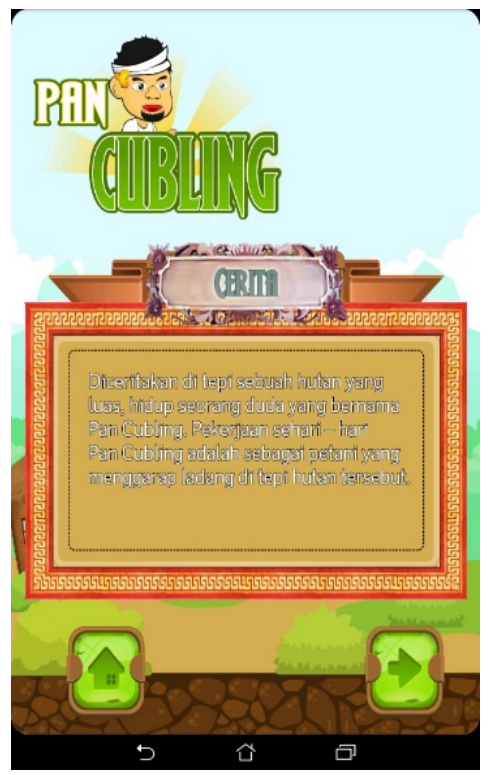

Gambar 15 Implementasi Tampilan Menu Cerita

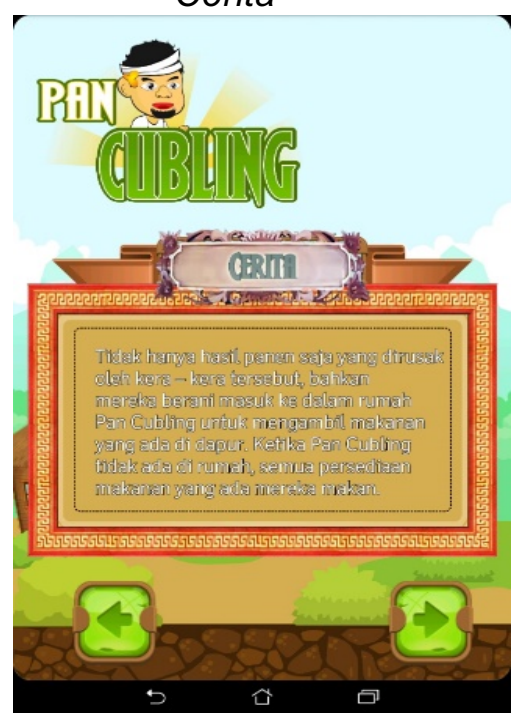

Gambar 16 Implementasi Tampilan Menu Cerita

Tampilan antarmuka menu cerita memiliki beberapa tampilan yang memuat cerita Pan Cubling. Di dalam game edukasi satua Bali Pan Cubling pemain bisa membaca secara keseluruhan cerita Pan Cubling yang disajikan dalam menu cerita yakni berupa teks dan narasi. di dalam tampilan menu cerita terdapat tiga tombol yakni tombol -3 home yang berfungsi apabila di tekan akan langsung kembali ke halaman menu utama. Tombol kedua yakni tombol $\rightarrow$ next yang berfungsi apabila ditekan akan pindah ke tampilan cerita 
selanjutnya. Dan tombol ketiga yakni tombol back yang berfungsi apabila ditekan akan kembali ke tampilan cerita sebelumnya.

Pengujian Perangkat Lunak

Pengujian perangkat lunak merupakan proses menjalankan dan mengevaluasi sebuah perangkat lunak untuk menguji apakah perangkat lunak sudah memenuhi persyaratan atau belum untuk menentukan perbedaan antara hasil yang diharapkan dengan hasil sebenarnya. Pengujian yang dilakukan antara lain: Blackbox Testing, Whitebox Testing dan Pengujian Ahli Isi, Ahli Media dan Pengguna.

Pengujian Blackbox Testing bertujuan untuk mengetahui kebenaran aplikasi Game Pan Cubling. Setelah dilakukan 2 kali pengujian dengan memakai kondisi yang berbeda, Game Pan Cubling tetap berjalan tanpa ada permasalahan.

Pengujian Whitebox Testing bertujuan mengetahui cara kerja suatu perangkat lunak secara internal. Pengujian dilakukan untuk menjamin operasi-operasi internal sesuai dengan spesifikasi yang telah ditetapkan dengan menggunakan struktur kendali dari prosedur yang dirancang. Setelah dilakukan 2 kali pengujian dengan memakai kondisi yang berbeda, Game Pan Cubling tetap berjalan tanpa ada permasalahan.

Uji Ahli Isi dilakukan pada seluruh bagian materi dari media aplikasi yang dikembangkan. Pada uji Ahli Isi, pengujian dilakukan oleh dua orang sebagai ahli isi yaitu Made Gelgel, S.Pd., M.Si sebagai Dosen pengampu mata kuliah Bahasa Bali di Jurusan Pendidikan Guru Sekolah Dasar Universitas Pendidikan Ganesha Singaraja Bali yang berasal dari Desa Petandakan, Buleleng, Bali dan I Ketut Sumitra, S.Pd.SD sebagai Kepala Sekolah SD Negeri 3 Pegadungan, Buleleng, Bali. Berdasarkan penilaian dari Ahli Isi oleh Made Gelgel, S.Pd., M.Si dan I Ketut Sumitra, S.Pd.SD dapat dianalisa keseluruhan penilaian yaitu $94 \%$, aplikasi Game Edukasi Satua Bali "Pan Cubling" berada dalam kriteria sangat baik

Uji Ahli Media dilakukan untuk menguji kesesuaian antara rancangan dengan hasil pengembangan aplikasi. Pada uji Ahli Media, pengujian dilakukan oleh 2 ahli, yaitu Bapak I Gede Mahendra Darmawiguna, S.Kom., M.Sc dan Bapak I Made Ardwi Pradnyana, S.T., M.T. Keduanya merupakan dosen dari jurusan Pendidikan Teknik Informatika. Berdasarkan penilaian dari Ahli Media Bapak I Gede Mahendra Darmawiguna, S.Kom., M.Sc. dan Bapak I Made Ardwi Pradnyana, S.T., M.T dapat dianalisa presentase keseluruhan penilaian yaitu $94,7 \%$.

Pembahasan

Aplikasi Game Edukasi Satua Bali "Pan Cubling" Berbasis Android dikembangkan dengan menggunakan IDE Android Studio dengan game engine AndEngine library untuk memudahkan dalam penggunaan fitur-fitur terkait pengembangan game pada Android Studio. Alur dalam pengembangan aplikasi Game Banten berbasis Android menggunakan proses SDLC yaitu 1)Analisis, menganalisis permasalahan terkait Satua Bali "Pan Cubling" sehingga didapatkan solusi untuk pembuatan aplikasi Game Edukasi Satua Bali "Pan Cubling" Berbasis Android; 2)Desain, merancang kebutuhan dan desain interface aplikasi Game Edukasi Satua Bali "Pan Cubling" Berbasis Android; 3)Developer, mengintegrasikan kode-kode program pada Android Studio sehingga aplikasi Game Edukasi Satua Bali "Pan Cubling" Berbasis Android dapat diimplementasikan; 4)Evaluasi, melakukan pengujian blackbox terkait proses jalannya tampilan aplikasi, whitebox terkait alur sistem aplikasi, ahli isi terkait kesesuaian isi satua Bali "Pan Cubling", ahli media terkait media tampilan aplikasi dan pengguna sebagai pemain dalam memainkan aplikasi Game Edukasi Satua Bali "Pan Cubling" Berbasis Android.

Di Bali sendiri kesusastraan sangatlah melekat erat dalam kehidupan masyarakat Bali. Baik yang digunakan dalam kegiatan keagamaan atau sebagai media hiburan. Salah satu contoh kesusastraan Bali yang digunakan dalam kegiatan keagamaan adalah kidung. Sedangkan kesusastraan Bali yang dipakai sebagai media hiburan contohnya adalah cerita yang biasa disebut "Satua". Menurut Gautama (2007), secara 
sempit yang disebut Satua Bali adalah satua - satua yang penyebarannya dari mulut - mulut dan tidak diketahui siapa penciptanya. Tetapi dalam pandangan luas, Satua Bali berasal dari karya - karya pengarang, baik yang berbahasa bali maupun yang berbahasa Jawa kuna. Satua - satua Bali baik yang masih lisan maupun yang sudah dicetak, banyak ditemukan di masyarakat. Satua Bali memiliki hubungan dengan kehidupan sehari - hari misalnya tentang kejujuran, kesetiaan, dan tidak boleh memaksakan kehendak. Orang tua zaman dulu sering menceritakan satua Bali kepada anak - anaknya sebagai dongeng pengantar tidur.

Di era globalisasi ini perkembangan teknologi sangat pesat sehingga semakin menurunkan minat anak - anak terhadap Satua Bali. Hal ini disebabkan makin merebaknya arus informasi dari penjuru dunia melalui media elektronik seperti televisi. Hampir setiap hari televisi menyuguhkan dongeng berupa film kartun. Kebanyakan film kartun tersebut adalah film kartun impor yang sangat digemari anak anak. Dibandingkan dongeng televisi, mendongeng secara langsung jauh lebih efektif dalam mendidik anak-anak sejak dini. Cerita dongeng memiliki nilai-nilai kebaikan seperti kejujuran, kesetiaan kerja keras, hingga sopan santun. Nilai-nilai ini akan dapat diserap anak-anak kalau dongeng tersebut dapat disampaikan dengan baik dan benar. Film kartun yang ditayangkan di televisi tidak seperti ibu dan anak yang bisa berkomunikasi secara langsung dengan anak atau cucunya. Pesawat televisi hanya bisa bercerita satu arah dan bersifat kaku, sehingga nilai-nilai dongeng tersebut tidak dapat diterima oleh si anak. ( Luh Suryani, Balipost 2002).

Sebelumnya telah dilaksanakan sebuah penelitian mengenai pengetahuan masyarakat Bali tentang satua Bali. Dari 20 responden, $79 \%$ menyatakan tidak mengetahui satua Bali sedangkan sebanyak $21 \%$ menyatakan mengetahui satua Bali. Hal ini tentu sangat memprihatinkan karena satua Bali merupakan salah satu unsur kebudayaan dibidang kesusastraan yang dimiliki oleh Bali. Sudah seharusnya masyarakat Bali mengenal kebudayaan mereka sendiri yang merupakan warisan leluhur.

Solusi yang perlu dibuat dari permasalahan tersebut adalah dengan memanfaatkan perkembangan teknologi. Dengan bantuan teknologi upaya dalam melestarikan kebudayaan Bali terutama Satua Bali dapat diupayakan. Dengan bantuan teknologi kita dapat memperkenalkan satua Bali kepada generasi muda. Game selain untuk sebagai hiburan dan tempat untuk menghilangkan stress, game juga bisa dijadikan alternatif media belajar bagi anak-anak. Contohnya adalah dengan menterjemahkan satua Bali ke dalam game edukasi. Berawal dari permasalahan di atas akhirnya muncul sebuah gagasan untuk membuat salah game yang menggunakan salah satua satua Bali sebagai sumber yaitu "Pengembangan Game Edukasi Satua Bali "Pan Cubling" Berbasis Android".

Revisi aplikasi setelah dilakukan uji coba mendapatkan saran perbaikan terutama dari segi media, hal ini dikarenakan media dari aplikasi Game Edukasi Satua Bali "Pan Cubling" dirasa masih kurang. Adapun saran yang diberikan yaitu, Status menang/kalah masih menutupi judul game, Desain stage perlu diperbaiki mengingat masih membingungkan mana yang termasuk stage 1, stage 2 dan seterusnya, penggunaan icon perlu disesuaikan dan backsound saat melempar batu disesuaikan dengan tema yang diambil yakni cerita tradisional harus menggunakan backsound yang natural atau tradisional.

Dalam penelitian pembuatan game 2D sebelumnya yang dilakukan oleh Dede Permana (2015) yang berjudul "Pengembangan Game Satua Bali I Siap Selem Berbasis Android", pada hasil penelitian yang dilakukan didapatkan bahwa aplikasi game yang dikembangkan dapat digunakan sebagai sarana guna menarik minat masyarakat dalam memperkenalkan satua I Siap Selem sehingga dapat dimainkan pada smartphone Android [8]. Hal itu sejalan dengan hasil pengujian respon pengguna pada aplikasi Game Edukasi Satua Bali "Pan Cubling" Berbasis Android yaitu 
pengguna merasa aplikasi ini menarik dan bermanfaat karena dapat menampilkan jalan cerita dari satua Pan Cubling dalam game.

Kelebihan dari aplikasi Game Edukasi Satua Bali "Pan Cubling" Berbasis Android ialah dalam penyajian cerita berbeda seperti yang disajikan dalam buku-buku maupun website, dalam aplikasi ini pengguna tidak hanya bermain sekaligus dapat mengenal Satua Bali Pan Cubling melalui fitu menu cerita yang tersaji di dalam game. Tampilan aplikasi Game Edukasi Satua Bali "Pan Cubling" Berbasis Android menggunakan desain dan alur proses yang sederhana namun tetap terlihat menarik. Tampilan aplikasi dibuat sesederhana mungkin dengan tujuan agar lebih memudahkan pengguna dalam memainkan aplikasi. Dalam hal ini tujuan peneliti sudah tercapai, itu terlihat pada hasil uji ahli isi, uji ahli media, dan uji pengguna yang mendapatkan hasil sangat baik. Peneliti menggunakan instruman musik Bali, dimaksudkan agar suasana menjadi lebih menyatu dengan permainan.

Kekurangan aplikasi Game Edukasi Satua Bali "Pan Cubling" Berbasis Android adalah aplikasi ini belum menggunakan fitur achievements dan google play games. pemain belum bisa terintegrasi dengan pemain yang lain terutama sejauh mana pencapaian yang sudah dicapai oleh masing - masing pemain. Tampilan karakter Pan Cubling hanya tampak dari belakang saja jadi belum terlihat secara spesifik bagaimana tam pilan karakter dari arah depan. Dalam pembuatan game, yang harus diperhatikan adalah bagaimana untuk bisa menarik perhatian pengguna, diharapkan kedepannya lebih ditonjokan dari segi animasi dan fitur-fitur menarik lainnya, sehingga dalam pengembangannya nanti tampilan terlihat sangat menarik perhatian pemain terutama anak - anak.

\section{SIMPULAN}

Berdasarkan hasil analisis, implementasi dan pengujian pada penelitian pengembanga aplikasi Game Edukasi Satua Bali "Pan Cubling" Berbasis Android, dapat ditarik kesimpulan sebagai berikut.
1. Rancangan aplikasi Game Edukasi Satua Bali "Pan Cubling" Berbasis Android metode yang digunakan adalah proses SDLC (System Development Life Cycle) dimana dalam metode ini menggunakan siklus air terjun (waterfall). Pada model SDLC liner waterfall memiliki alur yaitu: 1) Analisis Kebutuhan Perangkat Lunak, yaitu menganalis permasalahan terhadap suatu hal sehingga nantinya dihasilkan solusi dari permasalahan tersebut menjadi sebuah produk, 2) Desain, yaitu melakukan perancangan kebutuhan dan desain terkait produk yang akan dibuat, 3) Developer, yaitu mengintegrasikan kode-kode dalam suatu program sehingga produk dapat berjalan, 4) Implementasi yaitu melakukan implementasi antara kode dengan desain, penambahan fitu yang membuat produk menjadi semakin menarik, dan 5) Evaluasi, yaitu melakukan pengujian terhadap produk dengan uji isi, uji media, dan uji respon pengguna.

2. Implementasi aplikasi Game Edukasi Satua Bali "Pan Cubling" berbasis Android berupa sebuah aplikasi yang berisikan cerita atau satua dari Pan Cubling tersebut dibentuk sedemikian rupa ke dalam aplikasi game 2D yang dapat dimainkan dengan menampilkan objek gambar pada platform android versi 4.1 keatas.

3. Respon yang diperoleh dari Ahli Isi adalah bahwa isi cerita yang terdapat pada aplikasi Game Edukasi Satua Bali "Pan Cubling" Berbasis Android sudah sesuai dengan materi yang disampaikan, objek gambar telah sesuai, dan kesesuain penyajian cerita dengan presentase $94 \%$ yaitu sangat baik. Hasil dari pengujian Ahli Media disimpulkan bahwa aplikasi layak uji coba lapangan dengan revisi dan sesuai saran yang diberikan dengan presentase nilai $94,7 \%$ yaitu sangat baik. Kemudian hasil pengujian untuk mengetahui respon pengguna setelah memainkan aplikasi adalah semua pengguna setelah memainkan aplikasi menyatakan aplikasi Edukasi Satua 
Bali "Pan Cubling" Berbasis Android bermanfaat untuk membantu mengenal cerita atau satua Pan Cubling dengan presentase penilaian $99,07 \%$ yaitu sangat baik. Untuk penilaian UEQ yang telah dilakukan pengguna maka didapatkan daya tarik daripada aplikasi berada pada jenjang memuaskan (excellent), kejelasan aplikasi memuaskan (excellent), efisiensi baik (excellent), ketepatan aplikasi cukup baik (good), stimulasi memuaskan (excellent), dan kebaruan aplikasi memuaskan (excellent).

\section{REFERENSI}

[1] Teeuw, A. (2002: 23). Sastra dan IImu Sastra. Yogyakarta: Universitas Negeri Yogyakarta.

[2] Gautama, W. B. (2007). "Cakepan Panutun Mlajahin Kasusastraan Bali".
In Kesusasteraan Bali. Surabaya: Paramita.

[3] Kardji, I. W. (1991). Pupulan Satua Bali Banyol Jaruh. Denpasar: Fakultas Sastra Universitas Udayana.

[4] Clark,, D. (2006). Game and Elearning. Sunderland:: Caspian Learning.

[5] Hermawan, S. (2011). Mudah Membuat Aplikasi Android. Salatiga: Andi.

[6] Rustini, N.P. (2015). Survei Deskriptif Fitur-fitur pada Smartphone dalam Mendukung Kegiatan Akademis di Universitas Pendidikan Ganesha. Retrieved July 26, From : https://journal.uny.ac.id/index.php/jptk/a rticle/view/13188/9186

[7] Wibawanto, W. (2006). Membuat Game dengsn Macromedia Flash. Yogyakarta: C.V Andi Offset 